\title{
EXIT CONSENT SOLICITATIONS POST-ASSENAGON: A RELIC OF THE PAST?
}

\author{
Tsano Kanchev*
}

\begin{abstract}
This case note considers the Assenagon judgment, which reviewed the position of exit consent solicitations in English law. Exit consent solicitation is a restructuring technique utilised in cases where a company in financial distress seeks to reorganise its debts, more specifically its bonds. In order to avoid the strenuous process of insolvency, such bond issuers put forward an exchange offer, which permits the swap of distressed bonds for newly issued ones. The exchange offer is then coupled with an exit consent, which makes it a condition of the exchange that the bondholders firstly agree to an amendment of the original terms of the defaulting bonds. Such a move allows the issuer to reorganise its financial affairs in order to keep the company afloat. Briggs J did not see the purpose of exit consents positively. He held in Assenagon that such an exchange offer coupled with exit consents was invalid by virtue of the 'abuse principle' as the majority, at the invitation of the issuer, took part in 'coercing' the minority to swap their bonds. This case note outlines the key elements of Briggs J's ruling and discusses the future of exit consents post-Assenagon.
\end{abstract}

\section{A. INTRODUCTION}

In 2012, a decision delivered by the Chancery Division of the UK High Court of Justice received much attention from both academics and practitioners. ${ }^{1}$ The case, Assenagon $v$ Irish Bank Resolution, ${ }^{2}$ considered the legality of the technique known as exit consent solicitation, which is often used in the private out-of-court restructuring of companies in financial distress. ${ }^{3}$ Since the early 2000s, bond issuers in the London market have attempted to avoid the strenuous process of insolvency through such an exit consent workout, under which bondholders are permitted to exchange their distressed bonds for newly issued ones - provided they agree firstly

\footnotetext{
* LL.M. (University College London), LL.B. (University of Surrey).

${ }^{1}$ Stephen M Smith and Harry Sharpe, 'An Offer You Can't Refuse: When Does Coercion of a Group to Accept a Proposal Constitute Oppression of the Minority?' (2014) 29 Butterworths Journal of International Banking and Financial Law 288; Benjamin Liu, 'Exit Consents In Debt Restructurings' (2017) 13 Capital Markets Law Journal 116; Clifford Chance, 'Liability Management: Exit Consents and Oppression of the Minority' (31 July 2012) $<$ https://www.cliffordchance.com/briefings/2012/07/liability_managementexitconsentsan.html $>$ accessed 10 April 2020; Michael Doran and Sylvana Lee, 'Bond Exit Consents: no Way Out?' (White \& Case LLP, 30 August 2012) <https://www.whitecase.com/publications/article/bond-exit-consents-no-way-out> accessed 10 April 2020 .

${ }^{2}$ Assenagon Asset Management SA v Irish Bank Resolution Corp Ltd [2012] EWHC 2090 (Ch), [2013] 1 All ER 495.

${ }^{3}$ David C Ehmke, Bond Debt Governance: A Comparative Analysis of Different Solutions to Financial Distress of Corporate Bond Debtors (Nomos Verlagsgesellschaft, 2018) 238.

(C) 2020, The Authors. This is an open access article distributed under the terms of the Creative Commons Attribution License (CC BY) 4.0 https://creativecommons.org/licenses/by/4.0/, which permits unrestricted use, distribution and reproduction in any medium, provided the original author and source are credited - DOI: https://doi.org/10.14324/111.2052-1871.128.
} 
to modifying certain terms of their original bonds. ${ }^{4}$ Hence, only once the consent for the modifications has been received can the bondholders 'exit' and take advantage of the offer of the new bonds. The technique attempts to restructure the finances of the issuer in order to improve its financial health and enable it to continue trading. In the US -the birthplace of the technique- exit consents are utilised to circumvent the requirements of section 316(b) of the Trust Indenture Act 1939, which prohibits the alteration of payment provisions under the bonds without the consent of all the bondholders. In the UK, exit consents are instead used to manage holdout bondholders and ensure that they join the resolution to amend the terms of the bonds, which usually require a supermajority decision.

The court in Assenagon had the opportunity for the very first time to consider the legal position of exit consents under English law. Following the judgment, delivered by Briggs J, a question arose as to whether exit consents had become unlawful as he concluded that the sole function of exit consents was the "intimidation of a potential minority'. 5 This, he argued, offends the long-standing abuse principle, which seeks to protect an oppressed minority from the tyranny of the majority in the company and commercial context. ${ }^{6}$ He thus held that the resolution to exchange the bonds was invalid.

This case note argues that Assenagon did not invalidate the traditional form of exit consents; rather, it made the more extreme type of exit consents unlawful, which the mechanism can accommodate in the context of out-of-court restructuring schemes. The classical form of exit consents exists to limit the number of holdout bondholders in order to stabilise the financial position of the issuer. Any coercion resulting from this is only incidental and, in practice, does not always present itself since cooperation among the bondholders is often present in today's commercial world. As such, until a higher court weighs in on the matter, the archetype of the mechanism will still persist under English law.

In order to understand the reasoning of Briggs $\mathrm{J}$ in Assenagon, the note firstly discusses some of the key concepts addressed by the judgment. The origins and application of exit consents are outlined, after which the notion of the Prisoner's Dilemma is considered in the context of exchange offers. The foundations of the abuse principle, critical to Briggs J's reasoning, are then explored through some of the key English law cases, including the case of

\footnotetext{
${ }^{4}$ James Cole, 'How to apply US-style exchange offers in Europe' (2002) 21 International Financial Law Review 52.

${ }_{6}^{5}$ Assenagon (n 2) [84].

${ }^{6}$ ibid [86].
} 
Azevedo v IMCOPA, ${ }^{7}$ which affirmed the legality of payment consent solicitations. Following this overview, the case of Assenagon is reviewed and discussed.

\section{B. HISTORY AND CONTEXT OF EXIT CONSENTS}

Exit consents became popular in the US during the 1980s, a period known for the 'dynamic innovation of corporate transactions', ${ }^{8}$ which resulted in the rebirth of the 'junk bond' as it began to be utilised as a tool for funding newly formed ventures. ${ }^{9}$ The widespread use of junk bonds in the industry then resulted in higher than usual default rates in bond issues. ${ }^{10}$ Opportunity presented itself for more creative restructuring techniques to be applied. Bankruptcy was not desirable to bond issuers, as its consequences were more sizeable than required for defaulting bonds and it was disadvantageous to bondholders as it meant that they would not get the returns on their investment, which attracted them to the bonds in the first place. ${ }^{11}$ An alternative technique was bond repurchasing. This technique seemed inappropriate because if bond issuers had the funds to repurchase the distressed bonds, they would probably not require restructuring or, even if they did have the funds, they would only be able to repurchase a limited amount of bonds. ${ }^{12}$ An exchange offer then was clearly the preferred option. Under an exchange offer, bondholders would individually swap their distressed bonds for newly issued bonds, which contained terms that are more issuer-friendly -an example would be a clause that permits the issuer to take on more debt, even if the issuer is slightly behind on repayments of its loans (payment schedule). ${ }^{13}$ Under an exchange offer, the bondholders forfeit their right to enforcement of the old bonds. ${ }^{14}$

Any bondholders not participating in the exchange offer will preserve their rights under the original bonds and further increase the likelihood that the other bondholders will follow suit and similarly refuse to exchange their bonds. ${ }^{15}$ This is known as the 'holdout problem'. ${ }^{16}$

\footnotetext{
${ }^{7}$ Azevedo and another $v$ Imcopa Importacao, Exportaacao E Industria De Oleos Ltda and others [2013] EWCA Civ 364, [2015] Q.B. 1.

${ }^{8}$ Keegan S Drake, 'The Fall And Rise Of The Exit Consent' (2013) 63 Duke Law Journal 1590, 1595.

${ }^{9}$ Bryant B Edwards and Jon J Bancone, 'Modifying Debt Securities: The Search for the Elusive "New Security" Doctrine' (1992) 47 Business Law 571, 571-72.

${ }^{10}$ Patrick A Gaughan, Mergers, Acquisitions, And Corporate Restructurings (5th edn, John Wiley \& Sons 2011) 344-345.

${ }^{11}$ Drake (n 8) 1596.

12 ibid 1597.

${ }^{13}$ Apostolos Ath Gkoutzinis, Law and Practice of Liability Management: Debt Tender Offers, Exchange Offers, Bond Buybacks and Consent Solicitations in International Capital Markets (CUP 2014) 253-254.

${ }^{14}$ ibid.

${ }^{15}$ John C Coffee and William A Klein 'Bondholder Coercion: The Problem of Constrained Choice in Debt Tender Offers and Recapitalizations' (1991) 58 University of Chicago Law Review 1207, 1228-1229.

16 ibid.
} 
Holdout bondholders can either refuse to tender their distressed bonds because they are unable to see the benefits of the deal ('unenlightened' holdout bondholders) or because they seek to get full payment under the bonds once other creditors have agreed to grant the issuer debt relief ('opportunistic' holdout bondholders). ${ }^{17}$ Exit consents can make holding of the distressed bonds less attractive than exchanging them for the newly-issued ones by making it a condition to the exchange offer that the exchanging bondholders must first agree to certain changes to the terms of the original bonds before receiving the benefit of the new ones. ${ }^{18}$ As a result of these changes, the old bonds lose value and holdout bondholders are incidentally left with bonds of a lower value. In the US, a single holdout bondholder can stand in the way of the restructuring scheme since certain amendments of bonds require consent to be obtained from all the bondholders by virtue of section 316(b) of the Trust Indenture Act (TIA) 1939. Under section 316(b), any amendments seeking to impair or affect the right to receive principal or interest, or the enforcement of such rights, can only be adopted with the consent of every bondholder. ${ }^{19}$ Exit consents began to be used in order to circumvent this requirement and resolutions to remove restrictive covenants of bonds or approve the sale of company assets were adopted. ${ }^{20}$ In contrast to the position under US law, exit consents adopted in the UK are seen as an innovative use of the collective action clause in bonds which allows a majority of bondholders (usually a supermajority - over $75 \%$ of bondholders) ${ }^{21}$ to amend the terms of the bonds by adopting a resolution to that effect. ${ }^{22}$ Collective action clauses are useful where bonds are held by various entities or individuals that have competing interests, as they can resolve such conflicts and result in desirable reconciliations for the issuer and its creditors. ${ }^{23}$ Exit consents began to be used in order to increase the likelihood that the supermajority threshold is reached and the desired financial restructuring is achieved.

In their attempt to increase the possibility that the supermajority threshold is reached, exit consents incidentally create less of an incentive for bondholders to holdout. This disincentive presents itself in the form of a coercive element which is created by a Prisoner's Dilemma type situation, meaning that most bondholders opt for the exchange offer in fear of

\footnotetext{
${ }^{17}$ Lee C Buchheit and Mitu Gulati, 'Exit Consents in Sovereign Bond Exchanges' (2000) 48 UCLA Law Review $59,68$.

18 Gkoutzinis (n 13) 254.

19 TIA 1939, Section 316(a) provides an exception to this unanimity requirement for the postponement of the interest payment payable under the bond for no more than three years of its due date.

${ }^{20}$ Liu (n 1) 121.

${ }^{21}$ Buchheit and Gulati (n 17) 66.

${ }^{22}$ Royce de R Barondes, 'An Economic Analysis of the Potential for Coercion in Consent Solicitations for Bonds' (1994) 63 Fordham Law Review 749, 766-767.

23 ibid.
} 
losing out on the best value for their bonds. ${ }^{24}$ In certain cases (such as Assenagon) chances of the exchange offer being accepted can increase by adding a more punitive coercive measure for those who do not vote for the exchange.

\section{PRISONER'S DILEMMA}

The coercion element theoretically present in exit consents is said to be facilitated through the phenomenon known as the Prisoner's Dilemma. Such a phenomenon describes a situation where two or more rationally-thinking individuals, with no opportunity to cooperate, are presented with a choice they must make. Coffee and Klein revise the classical formulation of the Prisoner's Dilemma to a situation where bondholders, who do not collaborate with other bondholders must determine whether or not they should vote in favour of an exchange offer coupled with an exit consent. ${ }^{25}$ The following diagram represents the decisions that the individual bondholder can take and the outcomes of such a decision:

\begin{tabular}{|l|l|l|}
\hline Sufficient Others' Choice & Bondholder's Choice \\
\hline & Don't Tender & Tender \\
\hline Don't Tender & $\$ 500$ & $\$ 500$ \\
\hline Tender & $\$ 400$ & $\$ 450$ \\
\hline
\end{tabular}

In this example, the bondholder believes the bond to be worth $\$ 500$ and issuer offers an exchange price of $\$ 450$ for the bond. If the resolution is passed and the bonds are stripped of their protection, as requested by the exit consent, it is believed that the bonds would be worth $\$ 400$. Bondholders in this scenario are unaware of whether a sufficient number of other bondholders will exchange their bonds. If a sufficient number of others do exchange and the individual bondholder does not exchange, he will be left with bonds worth only $\$ 400$, which would be below the price offered by the issuer $(\$ 450)$. Conversely, if a sufficient number of bondholders do not exchange and the individual bondholder exchanges, the resolution would not be passed and the bondholders would be left with their current bonds which they believe to be worth $\$ 500$, as well as without a present buyer for this price. The optimum rational choice

\footnotetext{
${ }^{24}$ ibid 752.

${ }^{25}$ Coffee and Klein (n 15) 1231.
} 
for the individual bondholder in this matrix is hence to exchange, as he is at least less likely to end up with the lowest possible valuation of the bonds $(\$ 400)$. Hence all bondholders making this decision are more likely to exchange their bonds.

\section{Abuse Principle - History and Development}

In Assenagon it was alleged that the exit consent technique violated the abuse principle. ${ }^{26}$ The abuse principle was initially used to protect the minority decision makers from the tyranny of the majority in the company law context. It was applied as early as 1853 in Blisset $v$ Daniel $^{27}$ to the power of majority members of a partnership to expel one of its members by notice. Blisset objected to the appointment of one of his partner's son as a co-manager of the firm. The partner, whose son's appointment was rejected, then complained to the other partners and convinced them to make use of the clause in the partnership agreement that allowed a majority of partners to expel any other partner without any justification for the expulsion. The judge held that the power to expel was inserted not for the benefit of any particular partner but for the benefit of 'the whole society and partnership'. ${ }^{28}$ The application of the principle in the company law context was extended further by Re Westbourne Galleries ${ }^{29}$ and O'Neill v Phillips $^{30}$ as Blisset $v$ Daniel was applied to the relationship of shareholders in a limited company.

The basis for the principle appears to be the general principles of law and equity (and by implication). Allen $v$ Gold Reefs ${ }^{31}$ concerned a clause in the articles of association of a joint stock company, which gave a lien on all partly paid up shares held by the company members for any debt owed to the company. The plaintiff held both fully paid and partly paid up shares. Following his death, the company sought to change the provision in order to grant a lien on all fully paid up shares as well. The executers then sued to claim back the value of the fully paid up shares. Lindley MR stated that the power conferred to the majority shareholders to alter the articles of association must be exercised in accordance with the general principles of law and equity granted to majorities, which allowed them to bind minorities. This power, he argued, must be exercised 'bona fide for the company as a whole'. ${ }^{32}$ It was also alleged in Allen $v$ Gold Reefs that the amendment of the company's articles was in bad faith, as it specifically targeted

\footnotetext{
${ }^{26}$ Robert Peel, 'Assessing the Legality of Coercive Restructuring Tactics In UK Exchange Offers' (2015) 4 Journal of Law and Jurisprudence 162, 182.

27 [1853]10 Hare 493, 68 ER 1022.

28 ibid 524.

${ }^{29}$ Westbourne Galleries Ltd, In re [1973] AC 360 (HL).

${ }^{30}$ [1999] UKHL 24, [1999] 1 WLR 1092.

31 Allen v Gold Reefs of West Africa Ltd [1900] 1 Ch 656 (CA).

32 ibid 671.
} 
a certain deceased shareholder who owed the company a large amount of money. The court ruled that the amendment was not in bad faith, finding that the reason why the particular shareholder was targeted was because he was 'the only holder of paid-up shares, who at the time was in arrears' ${ }^{33}$ The case also evidences that an amendment, which has a practical effect solely on a number of discernible shareholders, can still be bona fide. In Shuttleworth v Cox Bros,${ }^{34}$ the Court of Appeal sought to adopt a subjective approach tested against objective criteria; the question was whether the members 'honestly believed that the exercise of the power was for the benefit of the company as a whole'. ${ }^{35}$ The case involved a provision under the articles of association of a joint stock company, which appointed certain directors for life, and was later amended to allow other directors to demand in writing the resignation of any other director.

The application of the abuse principle was also extended in the early $20^{\text {th }}$ century to the lending context. In British America Nickel Corpn, ${ }^{36}$ the principle was considered in relation to the power of a majority of debenture holders to modify the terms of the debenture, which was granted to the debenture holders under the terms of the trust deed. The modification of the debenture was carried out as part of a restructuring scheme. Viscount Haldane stated that the power given to the majority to bind the minority must be exercised 'for the purpose of benefiting the class as a whole and not merely individual members only'. ${ }^{37}$ The risk of abuse of power could also be addressed without the direct invocation of the abuse principle. In Mercantile Investment and General Trust Co v International Company of Mexico, ${ }^{38}$ Lindley LJ considered the ambiguities of language present in clauses that could potentially bind a dissenting minority. Here, a wide variety of powers could be invoked by the majority debenture holders to bind minority debenture holders to any release of the mortgages, of which the debenture was comprised. Lindley LJ stated that ambiguities in the language of the clause granting the powers in question should not be interpreted and used in cases which the provisions were not intended to meet. ${ }^{39}$

In Redwood Master Fund, ${ }^{40}$ the Court had the opportunity to consider collective action clauses in the context of a bond issuance. The claimants argued that the abuse principle should

\footnotetext{
33 ibid 675.

${ }^{34}$ Shuttleworth v Cox Bros \& Co (Maidenhead) Ltd [1927] 2 KB 9 (CA).

35 ibid 18.

${ }^{36}$ British America Nickel Corpn Ltd v O'Brien Ltd [1927] AC 369 (PC).

37 ibid 371.

38 [1893] 1 Ch 484 (CA).

39 ibid.

${ }^{40}$ Redwood Master Fund Ltd v TD Bank Europe Ltd [2002] EWHC 2703 (Ch), [2006] 1 BCLC 149.
} 
invalidate a decision taken by the majority lenders to alter the syndicated loan facility agreement. The syndicate had made a revolving credit facility (which was wholly underdrawn) and a term facility (which was almost completely drawn) available to the borrower. The borrower later anticipated a default which, under the terms of the facility agreement, would block the borrower's attempt to draw down further funds. In order to finance its working capital, the borrower sought to obtain a waiver of this restriction from the lenders. To grant such a waiver, the lenders required an overall reduction of the commitments under the facility. As such, the borrower insisted that the undrawn facility was used to pay off the commitments of the drawn facility. The claimants argued that the waiver was a violation of the abuse principle because the lenders of the drawn facility were enriching themselves at the expense of the minority members of the undrawn facility. The court held that the waiver was not an example of majority abuse of the minority. Although a small number of lenders of the undrawn facility were affected, which 'excited suspicion' as to the good faith of the majority, the majority did not in fact dictate the amendments to the borrower -the borrower aggressively negotiated this restructuring plan because it affected its repayment profile in the best possible way. ${ }^{41}$ It could not be determined from the evidence submitted, whether the majority was aware that some lenders could be prejudiced but Rimer J stated that they had no duty to investigate the percentage holdings of the lenders. ${ }^{42}$ The amendment further placed the borrower in the best possible financial position which was to the benefit of all lenders. Rimer J pointed out that conflicts of interest are inherent in such provisions and that it was almost impossible in practice for the majority to exercise such powers in a way which was objectively beneficial to each member of each class. ${ }^{43}$ In his view, all classes formed part of one long-term lending package.

\section{Payment Consent Solicitations - Azevedo}

Consent solicitations were considered for the first time in 2012. The case of Azevedo considered consent solicitations in the form of payment consents. The case concerned bonds with a face value of $\$ 100$ million that were issued by the Imcopa group, the largest Brazillianowned soybean processor by volume processed, as part of its refinancing programme. ${ }^{44}$ In an effort to service some of its outstanding financial obligations, Imcopa sought to obtain consent from its bondholders to change the terms of the bonds and anyone that consented to the changes was granted a payment. The changes included, inter alia, the postponement of an interest

\footnotetext{
41 ibid [116].

42 ibid [112].

43 ibid [94].

${ }^{44}$ Azevedo (n 7) [3].
} 
payment due otherwise in respect of the bonds. The consent payment was $\$ 25.94$ for every $\$ 1,000$ of the face value the bonds held which amounted to half of the amount of interest payment that was payable in respect of the bonds. ${ }^{45}$ The claimants argued that the consent payment offered to bondholders voting in favour of the resolution was in the nature of a bribe, thereby making the resolution illegal and invalidating the vote on it.

The court rejected the claimants' arguments, upholding the validity of the consent payments. Hamblen J firstly stated that by virtue of the authorities, consent payments do not constitute a bribery where the resolution at hand has 'openly provided for the separate treatment of persons with a different interest' ${ }^{46}$ and such persons were permitted to freely vote on the resolution. Hamblen J used the cases of Goodfellow v Nelson Line Liverpool ${ }^{47}$ and British American Nickel ${ }^{48}$ as authority for this claim. He also held that the consent payments had characteristics inconsistent with those of a bribery, fraud, or illegality -they were openly and repeatedly divulged and explained in the relevant documents available to all bondholders prior to each vote on the resolutions, they were payable on equal terms to all bondholders voting in favour of the resolution, and each bondholder had the right and ability to vote on the resolution as the bondholder saw fit. ${ }^{49}$ Hamblen $\mathrm{J}$ also recognised that consent payments were permitted under US law and used the Delaware case Kass v Eastern Airlines as persuasive authority. ${ }^{50}$ This reasoning led him to conclude that payment consent solicitations were lawful in English law.

\section{Exit Consent Solicitations - Assenagon}

Assenagon was the first case to consider the legality of exit consent solicitations under English law. Anglo Irish Bank, a bank incorporated in Ireland, had issued bonds of a nominal value of $€ 750$ million. ${ }^{51}$ The bank's primary lending activity was in the commercial property sector and as a result of the 2008 financial crisis, it appeared likely to face insolvent liquidation, unless it was rescued by the Irish Government. The Irish government provided financial support in the form of a two-year guarantee of some of the bank's liabilities (including the bonds subject to the exchange), nationalisation of the bank, and a number of capital injections. The bank then sought to issue new bonds, which it offered to its current bondholders in exchange for their old bonds as part of a restructuring plan. This exchange was to happen through an extraordinary

\footnotetext{
${ }^{45}$ ibid [17].

46 ibid [13].

${ }^{47}$ Goodfellow v Nelson Line (Liverpool) Ltd [1912] 2 Ch 324 (Ch).

${ }^{48}$ British America Nickel (n 36).

${ }^{49}$ Azevedo (n 7) [54].

${ }^{50}$ Kass v Eastern Airlines Inc [1986] WL 13008 (Del Ch).

${ }^{51}$ Assenagon (n 2) [10].
} 
resolution at a meeting where the bondholders would have had the opportunity to vote on the proposal. The resolution further gave the bank the right to redeem the old bonds for the value of $€ 0.01$ for every $€ 1000$ of principal bond value, which was significantly less compared to the offer to exchange the old bonds for the new ones at the exchange ratio of $€ 0.20$ worth of new bonds for every $€ 1000$ worth of the old ones. ${ }^{52}$ The exchange proposal also stated that the new bonds would be unsubordinated and guaranteed by the Irish government. Essentially, the bank proposed to alter the terms of the original bonds so as to avoid insolvency and any bondholder that voted to make these alterations was to receive new bonds, in exchange for their original bonds, with a face value equivalent to the current market value of the original bonds. The incentive of the exchange offer (which was the rate at which the bonds were currently trading) and the disincentive of the redemption right that the bank was to acquire from passing the resolution (which meant it could purchase the old bonds at an even lower value) resulted in the adoption of the resolution with a $92.03 \%$ majority. ${ }^{53}$ The claimant argued, inter alia, that the passing of the resolution was unlawful. It constituted an abuse of power of the majority bondholders voting because it conferred 'no conceivable benefit or advantage' on the whole class of bondholders and could only be construed as targeting the minority bondholders who did not seek to exchange their old bonds for the new ones. ${ }^{54}$ This, argued the claimant, was oppressive and unfair for the minority.

Firstly, Briggs $\mathrm{J}$ discussed the substance of the proposal. ${ }^{55} \mathrm{He}$ acknowledged that alleging minority abuse in cases where the offer of an inducement to support the scheme has been advanced to members of the class (not necessarily all members of the class) will be valid when the inducement has been divulged to all the members of the relevant class. ${ }^{56}$ Yet, he recognised that case law demonstrated that this is only acceptable in situations where the offer itself, disregarding the inducement, can be said to be beneficial to the class. ${ }^{57}$ In Goodfellow $v$ Nelson, many members of the class voted in favour of the scheme solely on its merits rather than by being affected by the coercive effect of the offer. ${ }^{58}$ Briggs $\mathrm{J}$ believed that this was not the case in Assenagon. In his view, it is also possible to invoke the abuse principle in cases where the coercive feature of the offer had been properly disclosed to the members of the

\footnotetext{
52 ibid [30].

53 ibid [36].

${ }^{54}$ ibid [83].

55 ibid [41]-[49].

56 ibid [72].

57 ibid.

${ }^{58}$ ibid.
} 
relevant class. ${ }^{59}$ He also acknowledged that the exchange offer presented the bondholders with real value in a time when the securities were considered to be distressed and there was a further threat of the value of the bonds advanced by the Irish government eroding in the form of legislative action. ${ }^{60}$ Nonetheless, he argued that Assenagon was a 'sharp contrast' to Goodfellow, as 'not a single noteholder can be said to have accepted it [the offer] unaffected by the coercive effect of the exit consent'. ${ }^{61}$

Secondly, Briggs $\mathrm{J}$ analysed the case of Azevedo and considered it in the context of Assenagon. In Azevedo, the inducement was also present in the form of consent payments, offered to all the members in exchange for their vote in favour of the resolution. Briggs $\mathrm{J}$ recognised that there was similarity between the payment consents technique used in Azevedo and the exit consent technique in Assenagon. ${ }^{62}$ However, he argued that the offer of the new notes is not, much like consent payments, a 'financial inducement' to vote to approve the resolution -rather the exit consent was used as a 'negative inducement' to 'deter' bondholders from voting against the exchange. ${ }^{63}$ Briggs $\mathrm{J}$ stressed that the similarities between the two cases were substantially fewer than their differences. ${ }^{64}$ The substance of the resolution in Azevedo was to postpone interest payments, whereas the resolution in Assenagon sought to substitute old bonds for new ones in a 'contractual exchange'. ${ }^{65}$ The Assenagon resolution sought rather to 'negatively induce' voters from voting against the exchange. ${ }^{66}$ In Azevedo, it was also the issuer who presented the financial inducement to the members of the class, whereas in Assenagon it was the majority bondholders who, at the invitation of the issuer, 'wielded the negative inducement' formed by the resolution. ${ }^{67}$ Briggs $\mathrm{J}$ also argued that the postponement of the interest in Azevedo was devised for the purpose of reorganising the debt of the issuer and could 'plainly' be considered to be beneficial to the bondholders, whereas the resolution in Assenagon was devised in a sense to 'destroy rather than enhance the value' of the bonds which was not, per se, beneficial to the bondholders. ${ }^{68}$ Finally, majoritarian abuse or oppression was not alleged in Azevedo but the claim centred primarily on the issue of bribery. ${ }^{69}$

\footnotetext{
${ }^{59}$ ibid [73].

${ }^{60}$ ibid [71].

${ }^{61}$ ibid [77].

${ }^{62}$ ibid [82].

${ }^{63}$ ibid [83].

64 ibid.

${ }^{65}$ ibid.

66 ibid.

${ }^{67}$ ibid.

${ }^{68}$ ibid.

${ }^{69}$ ibid.
} 
Ultimately, the key question for Briggs $J$ was whether it can be lawful for the majority to take part in coercing the minority by voting in favour of a resolution put forward by the issuer, which takes away the rights of the minority granted under the terms of the bonds in exchange for 'nominal consideration' ${ }^{70}$ The exit consent, he continued, was not utilised to reconstruct the issuer's finances by swapping the old bonds with new ones but instead served to grant the issuer a new right to redeem the old bonds for only a nominal consideration. ${ }^{71}$ This was unacceptable to Briggs $\mathrm{J}$ and he held that the resolution was invalid.

\section{OVERVIEW OF THE CURRENT ENGLISH LAW POSITION}

The judgment of Assenagon was not received without criticism. Liu argues that Briggs J conducted a faulty analysis of exit consents by treating the case as a classical oppression scenario and erred in his conclusion. ${ }^{72}$ A classical oppression scenario is one where a majority group seeks to pass a resolution that is substantially biased against the interests of the minority. In such a scenario, there is a discernible majority group of bondholders prior to the creation of the resolution. In a classical exit consent scenario, Liu argues, this is not the case. At the meeting when the vote on the resolution takes place, the bondholders exercise their voting power based on their own interests at the expense of any dissenting bondholders. ${ }^{73}$ Briggs $\mathrm{J}$ addressed this point. He acknowledged that prior to the vote on the resolution there is no discernible majority and minority. ${ }^{74}$ But inevitably, he argued, such a majority and minority are formed at the time of the vote. ${ }^{75}$ Such a characterisation does not seem to be contrary to established authorities. Even though the point was not directly addressed by any of the cases considering majority abuse of the minority, some insight can be found in Redwood. In Redwood, a judgment celebrated for being the most consistent with authorities on the abuse principle and for its appreciation of commercial realities, ${ }^{76}$ it was held that the lenders had no duty to investigate the circumstances of every other lender to determine, who would be negatively affected by the waiver. ${ }^{77}$ Rimer $\mathrm{J}$ opined that this exercise is not necessary. ${ }^{78}$ Thus, it is not a requirement of typical oppression scenarios that there must be a discernible majority and a discernible minority prior to the vote on the resolution.

\footnotetext{
70 ibid [84].

71 ibid.

${ }^{72}$ Liu (n 1) 132.

73 ibid.

${ }^{74}$ Assenagon (n 2) [85].

75 ibid.

76 Peel (n 26) 177.

${ }^{77}$ Redwood (n 40) [112].

78 ibid.
} 
On the issue of coercion, it is also submitted that Briggs J's analysis in Assenagon was erroneous since it did not appreciate the practical effect of the Prisoner's Dilemma-type coercion. Empirical evidence demonstrates that the Prisoner's Dilemma framework does not always apply in exit consent scenarios since coordination among the bondholders occurs more often than anticipated. Bab concluded from a research study involving 25 transactions that exit consents did not have a coercive practical effect since tender offers with coercive techniques attached to them were more likely to fail. ${ }^{79}$ Furthermore, Kehan and Tuckman discovered that in the beginning of the 1990s, bondholder co-ordination committees were set up in 12 out of the 58 tender offers in the study. ${ }^{80}$ Barondes further adds that a common misconception exists in the market about the nature of the bondholder, who is usually a 'large, sophisticated institutional buyer' that habitually communicates with other similar bondholders on such matters. ${ }^{81}$ On the other hand, there is also empirical evidence that observes instances of noncollaborative behaviour. Peterson argues that 'coercive elements probably do have some [positive] effect on the success of an offer' -a conclusion he drew from a much larger sample of 118 tender offers. ${ }^{82}$ Peel further comments that this study 'strongly supports' the argument that coercive techniques play a 'legitimate and useful' role in US exchange offers. ${ }^{83}$ There appears to be empirical evidence for either side of the argument. In a sense, this makes it inconclusive. It could be argued that there are circumstances under which bondholders could collude and reject an exchange offer if the terms of it are considered to be unfavourable. Certainly, nonetheless, it cannot be said that an exit consent can never be coercive and Assenagon appears to be an example of a case where the exit consent was, in fact, coercive.

A question then arises as to the impact of the Assenagon decision. ${ }^{84}$ Towards the end of his judgment, Briggs $\mathrm{J}$ appeared to invalidate the exit consent technique as he argued it was a 'coercive threat, which the issuer invites the majority to levy against the minority, nothing more or less'. ${ }^{85}$ Yet, he specified that his reasoning was based on the understanding of exit

\footnotetext{
${ }^{79}$ Andrew Bab, 'Debt Tender Offer Techniques and the Problem of Coercion' (1991) 91 Columbia Law Review 846, 879-885.

${ }^{80}$ Marcel Kahan and Bruce Tuckman, 'Do Bondholders Lose from Junk Bond Covenant Changes?' (1993) 66 The Journal of Business 499, 512.

${ }^{81}$ Barondes (n 22) 781.

${ }^{82}$ Lewis S Peterson, 'Who's Being Greedy? A Theoretical and Empirical Examination of Holdouts and Coercion in Debt Tender and Exchange Offers' (1993) 103 Yale Law Journal 505, 527.

${ }^{83}$ Peel (n 26) 171.

${ }^{84}$ Anna Gelpern, 'Exit Consents Killed in England?' (Credit Slips, 27 July 2012) $<$ https://www.creditslips.org/creditslips/2012/07/exit-consents-killed-in-england.html > accessed 10 April 2020, remarks that 'this decision takes away a major source of flexibility' and 'is a really big deal'.

${ }^{85}$ Assenagon (n 2) [84].
} 
consents that he outlined in the beginning of his judgment. ${ }^{86}$ In his view, the purpose of attaching exit consents to exchange offers is to 'impose a dissuasive constraint upon bondholders from opposing the exchange'. ${ }^{87}$ Such a definition, nonetheless, seems to misunderstand the purpose of basic exit consents. Arguably, the central feature of exit consents is to handle holdout bondholders by modifying the terms of the distressed bonds so as to ensure that the distressed bonds still do not put a strain on the financial position of the issuer postrestructuring. The coercive aspect of such exit consents (based on the Prisoner Dilemma phenomenon) can occur incidentally and need not be as coercive as in the case of Assenagon, as the modifications sought could include the removal of a negative pledge clause to incur more debt in an attempt to refinance or the alteration of the circumstances under which an event of default can be triggered ${ }^{88} \mathrm{~A}$ 'benefit' can be granted to bondholders in the exchange in an attempt to ensure that they get some sort of financial compensation which they might not receive in the event that the financial position of the issuer deteriorates ${ }^{89}$-in Assenagon, the new bonds carried a coupon of three months Euribor plus 3.75\% and were to be guaranteed by the Irish Government. ${ }^{90}$ The definition of exit consents adopted by Briggs $J$ is an accurate description of the more coercive or extreme variations of exit consents (such was in the case of Assenagon).

Despite Briggs J's reasoning, the exit consent technique appears to have a future postAssenagon. Leniham states that the case is not likely to present a challenge to exit consents containing 'drag along' clauses, under which dissenting bondholders are entitled to the same amount and type of consideration as the majority bondholders that approve the exchange. ${ }^{91} \mathrm{An}$ exit consent with a 'drag along' clause hence allows the dissenting bondholders who do not participate in exchanging their bonds to receive the newly issued bonds on the same terms as the majority bondholders that exchanged their bonds. Such a view is consistent with both the Assenagon decision, as well as subsequent authorities. Briggs $\mathrm{J}$ seemed to tacitly affirm the submissions of the claimant's QC that the Assenagon scheme was different than a 'drag along' where minority holders are granted the same rights as the majority. ${ }^{92}$ This scheme was held to be legally valid by the subsequent High Court decision in Re Cooperative Bank ${ }^{93}$ In this case,

\footnotetext{
86 ibid.

${ }^{87}$ Assenagon (n 2) [3].

${ }^{88}$ Peterson (n 82) 507; Ehmke (n 3) 154-157.

${ }^{89}$ Re Co-Operative Bank Plc [2017] EWHC 2269 (Ch), [2017] All ER (D) 146.

${ }^{90}$ Assenagon (n 2) [30].

${ }^{91}$ Paul Lenihan, 'Recent decisions on bond consent solicitations under English law' (2015) 30 Journal of International Banking Law and Regulation 163, 165.

${ }_{92}$ Assenagon (n 2) [76].

${ }^{93}$ Re Co-Operative Bank Plc (n 89).
} 
the restructuring plan offered the same benefits to both the majority and the minority bondholders, and it was pointed out how such a scheme avoided the potential outcome that the bondholders would get nothing, were the bank to collapse. ${ }^{94}$ Hence, 'drag along' clauses can even allow the more extreme exit consent variations to subsist - the ones which Briggs J dubbed negative inducements. In practice, such clauses strip these exit consents of their punitive aspect, leaving only the positive financial inducement that attracts bondholders to the exchange offer.

Corporate restructurings remain high in the UK. ${ }^{95}$ In 2019 some of Britain's household industry names entered administration or insolvency, such as Debenhams and more recently Thomas Cook. ${ }^{96}$ The number of companies falling into administration in 2019 has reached its highest level since the first economic quarter of $2014^{97}$ and high-yield bond default rates have set a new post-2007/2008 financial crisis record. ${ }^{98}$ It is therefore crucial that all tools are available in order to aid such financially ailing companies. Exit consents are an example of such a tool and they cannot be said to have lost their advantageous function to deter holdout bondholders. Re Cooperative Bank means practitioners are now more likely to use 'drag along' clauses, which by itself does not materially change the construction of exchange offers since exit consents envisage all bondholders (if possible) accepting the exchange offer and availing themselves of the benefits. It should be noted, however, that there has so far not been a case in a higher court to directly address the issues considered in Assenagon.

\section{E. CONCLUSION}

Exit consent solicitation is a technique which seeks to deal with the holdout problem in the context of out-of-court restructurings. In the US, a holdout bondholder can halt the entire exit consent resolution due to the requirement of unanimity. ${ }^{99}$ Under English law, a holdout bondholder can make it more expensive for the issuer to restructure. ${ }^{100}$ Coercion is therefore not at the heart of the technique; it is rather the modification of the terms of the old bonds in

\footnotetext{
94 ibid [47].

${ }^{95}$ Ed Macnamara and Jeremy Webb, 'Restructuring Trends: 2019 Trends and 2020 Year Ahead' $(P w C, 2020)$ $<$ https://www.pwc.co.uk/services/business-restructuring/insights/restructuring-trends/2019-trends-and-2020year-ahead.html $>$ accessed 10 April 2020.

${ }^{96}$ Sam Forsdick, 'Which UK companies have gone into administration in 2019?' NS Business(4 November 2019) $<$ https://www.ns-businesshub.com/business/uk-companies-administration/> accessed 10 April 2020.

97 The Insolvency Service, Company Insolvency Statistics, Q3 July to September 2019 (30 October 2019) $<$ https://assets.publishing.service.gov.uk/government/uploads/system/uploads/attachment_data/file/856060/Com pany_Insolvencies_-_Commentary___Q3_2019.pdf> accessed 10 April 2020.

${ }_{98}$ Joy Wiltermuth, 'High-yield Defaults on Track for Postcrisis Record' The Wall Street Journal (19 August 2019)

$<$ https://www.wsj.com/articles/high-yield-defaults-on-track-for-postcrisis-record-11566225333> accessed 10 April 2020.

${ }^{99}$ TIA Section 316(b) 1939.

${ }^{100}$ Peel (n 26) 187.
} 
order to deal with the minority holdout bondholders so that the company can avoid insolvency. Such bondholders in English law can defeat the purpose, for which the workout was sought in the first place since some of the savings made from the bonds exchange would be used to compensate these minority bondholders. ${ }^{101}$ In support of this point, Peterson concludes from reviewing the data of his study that the real problem most likely lies with 'greedy individuals holding out' because in most unsuccessful exchange offers, the bondholders would have been 'better off' had they accepted the offer. ${ }^{102}$ The negative coercion aspect need not be present for exit consents to work, although it might in theory (not necessarily in practice) ${ }^{103}$ make it more likely that the bondholder accepts the exchange offer attached to the exit consent. Under a less extreme variation of an exit consent, such a coercive effect is only created in an ancillary capacity by virtue of the Prisoner's Dilemma when newly issued shares are granted to bondholders to ensure that the financial state of the company does not worsen and make these bondholders worse-off. ${ }^{104}$ Assenagon presents a more extreme case of an exit consent where bondholder coercion played a central role, one that Briggs J denied as unacceptable. The exit consent solicitation technique thus lives on by virtue of Re Cooperative Bank and it should continue to subsist in this key variation, providing a legitimate solution to a legitimate problem.

\footnotetext{
101 ibid.

102 Peterson (n 82) 509.

103 ibid.

${ }^{104}$ Re Co-Operative Bank Plc (n 89).
} 